\title{
LEVÉHO MÁCHOVSKÉ STUDIE A NOVÝ ANGLICKÝ PŘEKLAD „MÁJE“
}

\author{
STANISLAV RUBÁŠ
}

\begin{abstract}
This paper deals with "May", an 1836 poetic masterpiece by the Czech Romantic poet, Karel Hynek Mácha (1810-1836). First, it briefly recounts the findings of Jiř́ Levý (1950) and Stanislav Rubáš (2012) concerned with "May" in its renderings into English. Having analysed various English versions of Mácha’s poem, both translation scholars reveal how the poetic potential, or muse, of the respective translators have been moulded by their target language cultures, especially in terms of the florid excess of Victorian poetry and of Romantic fatalism, the stock-intrade of Romantic poetry, coined by George Gordon Byron. Second, the paper examines a new (so far unpublished) English translation of "May" by UIC Professor Alfred Thomas. Juxtaposing some of the main passages of the original (mostly from Canto 1) with their new English version, the author reveals a number of metrical and semantic shifts, shortcomings as well as obvious mistakes. Third, for the sake of contrast and comparison, the present article shows how a 1932 translation of "May" made by Roderick A. Ginsburg excels over the new rendering both in accuracy and poetic qualities.
\end{abstract}

Key words: poetry translation, Jiř́ Levý, Mácha’s May in English

Máchův „Máj“ vyšel zatím v šesti kompletních anglických překladech. Jejich historie začíná v roce 1932, kdy Máchovu básnickou skladbu vydal ve Spojených státech soukromým tiskem její překladatel Roderick A. Ginsburg, původem z Čech. Poté následovaly verze Hugha H. McGoverna (1949), Edith Pargeter (1967), Williama E. Harkinse (1987), Jamese Naughtona (2000) a Marcely Sulak (2005). Vedle těchto úplných variant existuje i jeden torzovitý, volným veršem psaný pokus o překlad „Máje“ z pera anglického básníka Stephena Spendera (1943). ${ }^{1}$

Jiř́i Levý věnoval cizojazyčným překladům Máchova „Máje“ celkem dvě stati. První $\mathrm{z}$ nich vyšla $\mathrm{v}$ roce 1950 a má charakter syntetizující studie, která v řadě dílčích postřehů dokládá zejména jedno: jak se převodem do jiných kultur proměnil „Máchův stylistický i ideový fond“ (Levý 1971: 158). ${ }^{2}$ Bližší pozornost Levý věnuje ruskému překladu Bocha-

1 Okolnosti vzniku a publikace tohoto překladového torza komentuje Jiř́ Levý (Levý 1971: 159).

2 Studie vyšla poprvé v roce 1950 (Levý 1950) a poté byla přetištěna v roce 1971 (Levý 1971). 
novu z roku 1930, italskému překladu Selviho z roku 1934 a francouzskému překladu Jelínkovu a Pasquierovu z roku 1936. Dominantní roli v Levého máchovské studii ovšem hraje anglický překlad McGovernův z roku 1949. Z množství Levého postřehů k této verzi „Máje“ i z jejího vročení se zdá, že právě tento anglický „Máj“ českého badatele motivoval k souhrnnějšímu pohledu na osudy Máchovy básně v cizině. Tuto domněnku ostatně potvrzuje i druhá autorova máchovská stat', která se k McGovernovu překladu vrací v podobě časopisecké recenze (Levý 1950).

V roce 2009 jsme na Levého máchovské studie navázali vlastním rozborem všech kompletních anglických a ruských překladů „Máje“ (Rubáš: 2012). ${ }^{3}$ Naše srovnávací práce přitom zahrnovala i převody, jimž se Levý věnoval bud’ jen okrajově, nebo vznikly až po jeho smrti.

Z naší konfrontace Máchova originálu s jeho anglickými a ruskými variantami - ve shodě se závěry Jiřího Levého - především vyplynulo, že původci těchto překladů „Máje“ přicházejí s řešeními, jež nesou stopy myšlenkových stereotypů př́íslušných cizích kultur: do překladů McGoverna a Pargeterové pronikly prvky byronovského fatalismu a bujně květnatá dikce viktoriánské angličtiny, zatímco v ruských převodech Bochana (1930), Nedzelského (1936) a Lugovského a Golemby (1959) se ozývá spiritualita ruského pravoslaví (Rubáš 2012: 185). ${ }^{4}$ Náš rozbor přitom poukázal i na další tendenci máchovských překladatelů: poslední dva anglické překlady „Máje“ opouštějí Máchovy rýmy a celou báseň převádějí volným veršem. Jak poznamenává Marcela Sulak: „Nepokoušela jsem se reprodukovat Máchovy rýmy [...]. Rýmované verše znějí v češtině přirozeně, nebot tento jazyk disponuje sedmi pády a mimořádně ohebnou větnou stavbou. [...] Stavba anglické věty tak ohebná není a angličtina ani nemá tolik rýmových dvojic jako čeština. Snaha napodobit Máchovy rýmy by $\mathrm{v}$ angličtině vedla $\mathrm{k}$ větným deformacím, jež by na sebe poutaly příliš mnoho pozornosti - na úkor mimořádně invenčních metafor a přirozené hudebnosti originálu." (Sulak 2005: 14)

Před nedávnem jsme měli možnost seznámit se s dosud nepublikovaným anglickým překladem „Máje“ od Alfreda Thomase, profesora UIC (University of Illinois at Chicago). Této nové verzi Máchovy básně, kterou překladatel nabídl k publikování Nakladatelství Karolinum, bychom zde chtěli věnovat hlubší pozornost - v návaznosti na Levého i naše vlastní máchovské bádání. 6

Jestliže Levý ve své máchovské studii mluví o dvou vlnách silnějšího zájmu ciziny o „Máj“, a to po Máchově smrti a pak, v mohutnějším vydání, ve třicátých letech 20. století (Levý 1971: 158), pozorujeme s nástupem nového tisíciletí výraznou vlnu třetí, jež započala překlady Naughtona (2000) a Sulakové (2005) a nyní pokračuje novou verzí „Máje“ vytvořenou Alfredem Thomasem.

3 Podnětem k této nové analýze byla mezinárodní konference Ústavu translatologie FF UK pořádaná ve zmíněném roce na téma Translating Beyond East and West. Konference měla mimo jiné za cíl konfrontovat „západni““ a „východní“ kulturní stereotypy skrze překladatelské interpretace literárních děl.

4 Tento „dotyk pravoslavi“ je $\mathrm{v}$ případě Lugovského a Golemby navíc paradoxně kombinován s důrazem na fanaticky nepřátelský dav přihlížející popravě hlavního hrdiny.

5 Citováno v překladu autora této stati.

6 Za povšimnutí stojí už sám fakt, že Thomas pojal úmysl vydat svůj překlad v České republice. Rozhodl se tak pokračovat v tradici anglických „Májü“ vydaných v Praze, kterou založil Hugh H. McGoverne (Orbis) a v níž pokračovala Edith Pargeterová (Artia) i Marcela Sulaková (Twisted Spoon Press). 
Na rozdíl od dvou bezprostředně předcházejících anglických převodů Thomas zachovává Máchovy rýmy, což je samo o sobě hodno respektu. Rovněž celková dikce jeho „Máje“ má své kvality, zejména ve srovnání se starším, viktoriánsky rozkošatělým překladem McGovernovým. Thomas hledá vlastní výrazovou cestu. V doslovu ke svému „Máji“ sám říká: „Během překládání jsem zjistil, že používám shakespearovskou angličtinu, třebaže jazyk Máchův je plně prostoupen duchem evropského romantismu. "7 Také Thomas však přiznává: „I když jsem se snažil vyvarovat květnatosti viktoriánské poezie, nevyhnul jsem se nakonec vlivu některých anglických romantiků, hlavně Williama Wordsworthe, znamenitého prrírodního lyrika.“

Co se však čtenáři nového anglického „Máje“ vyjeví při srovnání s Máchovým originálem? Sledujme podrobněji první zpěv básně, nejprve úvodní verše:

Byl pozdní večer - první máj - (8)
večerní máj - byl lásky čas. (8)
Hrdliččin zval ku lásce hlas, (8)
kde borový zaváněl háj. (8)
O lásce šeptal tichý mech; (8)
květoucí strom lhal lásky žel, (8)
svou lásku slavík růži pěl, (8)
rǔžinu jevil vonný vzdech. (8)
Jezero hladké v křovích stinných (9)
zvučelo temně tajný bol, (8)
břeh je objímal kol a kol; (8)
a slunce jasná světů jiných (9)
bloudila blankytnými pásky, (9)
planoucí tam co slzy lásky. (9)

Byl pozdní večer - první máj - (8)

Hrdliččin zval ku lásce hlas, $(8)$

kde borový zaváněl háj. (8)

O lásce šeptal tichý mech; $(8)$

květoucí strom lhal lásky žel, (8)

svou lásku slavík růži pěl, (8)

Južnu jevil vonný vzdech. (8)

zvučelo temně tajný bol, $(8)$

břeh je objímal kol a kol; $(8)$

a slunce jasná světů jiných $(9)$

planoucí tam co slzy lásky. (9)

\author{
Late evening it was - the first of May - (9) \\ May's eventide - the time of love. (8) \\ Love heard the voice of the turtle-dove (9) \\ Where the pine groves sigh and sway. (7) \\ The silent moss told its amorous tale (9) \\ And the blooming tree feigned lovers' grief, (9) \\ While the rose, concealed beneath the leaf, (9) \\ Breathed fragrance to the nightingale. (8) \\ The glassy surface of the lake (8) \\ Murmured darkly of love's disgrace, (8) \\ Wrapped tightly in the bank's embrace; (8) \\ And the bright suns soon forsake (7) \\ Their orbits in the sky above, (8) \\ Trickling down like tears of love. (7) ${ }^{9}$
}

Mácha používá čtyřstopý jamb, tj. osmislabičný verš ( $\mathrm{v}$ př́padě mužského rýmového zakončení), nebo verš devítislabičný (v případě ženského rýmového zakončení). Př́slušný počet slabik uvádíme v závorce za každým veršem. Rýmové schéma je a-b-b-a / c-d-d-c / e-f-f-e / g-g, tj. jsou tu třikrát rýmy obkročné následované jedním rýmem sdruženým. Předchozí čtrnáctiřádková pasáž tvoří de facto samostatnou báseň ve formě sonetu (se shakespearovským kupletem na konci).

Překladatel střídá verše sedmislabičné, osmislabičné a devítislabičné (bez ohledu na rýmové zakončení). Tato formální svévole způsobuje, že Máchova báseň hned v úvodu ztrácí kus své hudebnosti. Řečeno obrazně: zatímco Mácha zpívá, Thomasův překlad od počátku jaksi nemůže popadnout dech.

Svým rytmem i zvukomalbou se Máchovi mnohem více blíží rýmovaný překlad Ginsburgův (za předpokladu, že při hlasitém čtení redukujeme neurčitý člen u slov „a nightingale“, „a rose" a „a muffled sound“):

\footnotetext{
Tato i další pasáže z Thomasova doslovu jsou citovány podle rukopisu a v překladu autora této stati.

Tato i další části „Máje“ jsou citovány podle souborného vydání Máchových spisů (Mácha 1986).

Tyto i další verše z Thomasova překladu jsou citovány podle rukopisu.
} 
Byl pozdní večer - první máj - (8)

večerní máj - byl lásky čas. (8)

Hrdliččin zval ku lásce hlas, (8)

kde borový zaváněl háj. (8)

O lásce šeptal tichý mech; (8)

květoucí strom lhal lásky žel, (8)

svou lásku slavík růži pěl, (8)

růžinu jevil vonný vzdech. (8)

Jezero hladké v křovích stinných (9)

zvučelo temně tajný bol, (8)

břeh je objímal kol a kol; (8)

a slunce jasná světů jiných (9)

bloudila blankytnými pásky, (9)

planoucí tam co slzy lásky. (9)
'Twas late at eve... the first of May, (8)

A night in May... 'twas time for love. (8)

A love lure sang the turtle-dove, (8)

Where scented pine groves stretched away. (8)

The tranquil moss sighed love's lament; (8)

Love's sorrow shammed the blooming tree, (8)

A nightingale sang love's melody, (8)

While a rose replied with love's sweet scent. (8)

The lake, hid where the thicket reared, (8)

Expressed its grief in a muffled sound, (8)

Where banks entwined it all around; (8)

The suns of other worlds appeared (8)

And strayed across the azure spheres, (8)

Gleaming above like love's bright tears. (8)

Za pozornost ovšem stojí i významová stránka obou překladů. Obrat May’s eventide (večerní čas máje), který najdeme u Thomase, je básnicky adekvátnější řešení než Ginsburgovo spojení a night in May (noc v máji), jak vyplývá z Mukařovského rozborů Máchovy poetiky: „... spojení jako večerní máj, jitřní máj, pưlnoční krajina, májový dol, jezerní dálka [...]. Společná vlastnost všech je ta, že adjektivum jednou ze základních složek svého významu je v rozporu se substantivem; tak např́klad ve spojení večerní máj rozchází se adjektivum se substantivem v tom, že samo značí kratší úsek časový než substantivum, které je jím určeno." (Mukařovský 1948: 248-249). Tento rozpor má pak za následek, „že významové jádro slova máj se nestane významovou osou, ba že dokonce pro rozpor s významem adjektiva večerní vystoupí ve vědomí jen velmi slabě. Tím celý výraz večerní máj pozbude pevné významové struktury a akcesorní významy, nemajíce pevného středu, se rozvlní v celé své pestré měnivosti: ze slova máj vycítíme jarní rozkvět, vůni, ptačí zpěv atd., ze slova večerní pak stmívání, utichání, měsíční svit atd. Nastane střídavé vynořování a zapadání jednotlivých nejasných významů, a tak vzniká dojem zastřenosti věcného významu [...]." (Mukařovský 1948: 114) Téhož dojmu zastřenosti dosahuje Thomasův obrat May's eventide, vyvolávající podobné př̀edstavy, jaké popisuje Mukařovský.

Naopak Ginsburgův verš a love lure sang the turtle-dove (o vábení lásky zpívala hrdlička) je přesnějším odrazem předlohy než Thomasovo mlhavě neurčité tvrzení, že love heard the voice of the turtle-dove (láska zaslechla hlas hrdličky), o jehož smyslu se čtenář může jen dohadovat.

Významově poněkud zmatený je také Thomasův překlad samotného závěru dané pasáže:

a slunce jasná světů jiných

bloudila blankytnými pásky,

planoucí tam co slzy lásky.
And the bright suns soon forsake

Their orbits in the sky above,

Trickling down like tears of love.

Máchův obraz zachycuje, jak se slunce jasná neboli hvězdy odrážejí na hladině jezera a tvoří tak blankytné pásky neboli záblesky. Namísto působivého (a veskrze logického) Máchova obrazu čteme v překladu verše o jasných sluncích (bright suns), která opustila 
své oběžné dráhy na nebi (forsake their orbits in the sky above), aby stekla dolu jako slzy lásky (trickling down like tears of love). Pro úplnost dodejme, že s výjimkou Naughtonovy verze jsou všechny anglické převody „Máje“ v tomto místě zavádějící. Naughton překládá správně, ovšem bez dodržení veršového rozměru a rýmů:

a slunce jasná světů jiných

bloudila blankytnými pásky,

planoucí tam co slzy lásky.
And the bright suns of other worlds

Wandered in azure stripes,

Burning there like tears of love. ${ }^{10}$

Významová mlhavost a rytmická nepravidelnost provázejí i další místa Thomasova překladu:

Dál blyštil bledý dvorů stín, (8)

jenž k sobě šly vzdy blíž a blíž, (8)

jak v objetí by níž a níž (8)

se vinuly v soumraku klín, (8)

až posléz šerem vjedno splynou. (9)

S nimi se stromy k stromům vinou. (9)
Pale shadows in the growing gloom (8)

Closer and closer turn their face (8)

Deeper and deeper in love's embrace, (9)

Weaving together the twilight's womb (9)

Until they merge forever. (7)

With them the trees weave together. (8)

V překladu zmizel máchovský obraz dvorů, přesněji jejich bledého stínu, který Naughton pak překládá doslova jako pale farms' shade. Tento obraz se v „Máji“ několikrát vrací a je namístě ho zachovat, a nikoliv zrušit. Thomasova rýmová dvojice forever - together pak působí vyloženě nelibozvučně.

V novém překladu prvního zpěvu „Máje“ najdeme i některá zdařilejší místa. Ani ta však neobstojí ve srovnání s překladem Ginsburgovým:

Nejzáze stíní šero hor, (8)

tam bříza $\mathrm{k}$ boru, $\mathrm{k}$ bříze bor $(8)$

se kloní. Vlna za vlnou (8)

potokem spěchá. Vře plnou - (8)

v čas lásky - láskou každý tvor. (8)

Nejzáze stíní šero hor, (8)

tam bříza $\mathrm{k}$ boru, $\mathrm{k}$ bříze bor (8)

se kloní. Vlna za vlnou (8)

potokem spěchá. Vře plnou - (8)

v čas lásky - láskou každý tvor. (8)
Far away grey mountains perch. (7)

There birch to pine, pine to birch (7)

Incline; and through the little brook (8)

Wave chases wave. With ardent look - (8)

Each earthly thing for love does search. (8)

[Thomas]

Where dusk and mountain tops entwine, (8)

Sways pine with birch and birch with pine, (8)

The speeding waves new waves submerge (8)

Within the brook. - All feel the urge (8)

When love time comes, to seek love's shrine. (8)

[Ginsburg]

Ginsburg dodržuje veršový rozměr předlohy, používá nápadité rýmy a zachovává světelné efekty Máchových obrazů. Tam, kde má Thomas unylý popis v dálce se tyči šedé hory (far away grey mountains perch), najdeme u Ginsburga mnohem máchovštější představu kde se soumrak a vrcholky hor pojí vjedno (where dusk and mountain tops entwine).

Následujícímu Máchovu obrazu pak Thomas vůbec neporozuměl:

10 Tyto i další úryvky z Naughtonova překladu citujeme podle jeho internetové verze (Naughton 2000). 
Štíhlé se veslo v modru koupá, a dlouhé pruhy kolem tvoří. Těm zlaté růže, jenž při doubí tam na horách po nebi hoří, růžovým zlatem čela broubí.
Slim oars cleave the dark blue lake Creating deep stripes as they glide. Golden roses hang from bushes Which grow along the mountain-side And gild them as it onward rushes.

Překlad vykresluje představu skutečných zlatých růži (golden roses), které visí na keřich (hang from bushes) rostoucích na horském svahu (which grow along the mountain-side) a pozlacují (gild) pruhy (stripes) neboli hřebeny vln tvořené záběry štíhlých vesel (slim oars) na jezerní hladině. Máchovy zlaté růže, které po nebi hoří, ovšem označují večerní červánky a rozvíjejí obraz růžového večera, za něhož hrdinka básně vyhliží příjezd milovaného muže. Jedině takto metaforicky míněné zlaté růže se mohou odrážet na hřebenech vln. Ginsburg, na rozdíl od Thomase, uvedené verše opět překládá brilantně po formální i obsahové stránce:

Štíhlé se veslo v modru koupá, a dlouhé pruhy kolem tvoří. Těm zlaté růže, jenž při doubí tam na horách po nebi hoří, růžovým zlatem čela broubí.
A slender oar appears to tease The churning waters, forming rings. Each foaming ring an oar enslaves While borne from skies on gilded wings, Roses of gold ride on the waves.

Dokonce i dějově nejdramatičtější místo prvního zpěvu Thomas narušuje výrazně rozkolísaným temporytmem:

„... Za hanu jeho, za vinu svou (9)

měj hanu světa, měj kletbu mou!“ (9)
“... For your guilt, for his endless shame (8) Take my everlasting curse, take the world's blame!" (11)

Srovnejme znovu s rytmicky přesným a významově vypointovaným překladem Ginsburgovým:

„... Za hanu jeho, za vinu svou (9)

měj hanu světa, měj kletbu mou!“" (9)
“... For his disgrace and for your vice (8)

Have world's disgrace... Be cursed thrice!” (8)

V podobném srovnávání bychom mohli pokračovat dál. Protože však uvedené př́íklady z prvního zpěvu zřetelně dokládají nedotaženost Thomasova překladu, omezíme se už jen na dvě místa ze zpěvu třetího, která nejvíce vystupují do popředí.

Př́klad první:

poklekl k zemi, kat odstoupí, strašná chvíle pak blyskne meč, kat rychlý stoupne, krok

vkolo tne meč, zločinci blyskne v týle,
Kneels on the earth; the hangman lifts the sword to his breast; It flashes through the neck, the hangman steps around, 
upadla hlava - skok i -

ještě jeden skok -

i tělo ostatní ku zemi ted' se skloní.

Ach v zemi krásnou, zemi milovanou,

v kolébku svou i hrob svůj, matku svou,

v vlast' jedinou i v dědictví mu danou,

v šírou tu zemi, zemi jedinou,

v matku svou, v matku svou, krev
The head falls down - bounces - bounces

on the mound -

While the trunk collapses on the ground.

Into the lovely earth, beloved earth of mine,

My cradle and my grave, my mother true,

My only homeland, my only precious shrine, Wide earth, my only inheritance is you. Into the mother, into the mother, the son's

blood flows around.

Kromě vynechání verše vkolo tne meč, zločinci blyskne v týle překladatel změnou rýmového schématu zbavil vrcholnou pasáž třetího zpěvu „Máje“ velkého rétorického a zvukového efektu: hrdina básně naposledy prodlévá pohledem na šíré zemi a toto prodlení se odráží v rýmové dvojici skloní - po ní, kterou od sebe oddělují čtyři dlouhé verše. Místo tohoto efektu v překladu nacházíme řadu rýmů, jež Máchovým veršům dávají docela jiný charakter: around - mound - ground - around. Toto rýmování připomíná spíš kramářskou píseň než vrcholné místo romantické básně.

A druhý př́iklad z téhož zpěvu:

na mrtvé tváři mu poslední dřímá sen. Na něj se dívajíc - po celý dlouhý den nesmírné množství vkol mala pahorku stálo; teprv až k západu schýlivši slunce běh veselo v mrtvý zrak staté hlavy se smálo, Unt utichl jezera šírý - večerní břeh.
On the dead face a last dream slumbers

While all around the vast crowd lumbers. All day long they stare at the bloody trunk,

Laughing happily at the staring, empty eyes, Until the sun in the west had sunk And noise on the evening lake subsides.

V překladu se uvádí, že početný dav (vast crowd) se štastně smál (laughing happily) při pohledu do vytřeštěných, prázdných očí (the staring, empty eyes), tj. očí, kterými hleděla utatá hlava zbojníka Viléma. Z originálu je nicméně zřejmé, že pokud se v dané chvíli někdo směje, je to zapadající slunce, nikoli okolní dav. Vztah lidu k hlavnímu hrdinovi tu byl dezinterpretován možná omylem, avšak velmi podobně jako v překladu Hugha McGoverna, komentovaném Jiřím Levým (1971: 163-164): „Rozdíl anglického a českého pojetí se projevil také při výkladu poměru mezi Vilémem a davem, který přihlíží popravě. $\mathrm{V}$ duchu anglického byronismu tlumočil překladatel tento poměr jako nepřátelský vztah mezi zneuznaným výjimečným jedincem a nechápavou luzou: On to your doom, Dread Forest Lord!; Hushed the hostile murmur loud. V pojetí Máchově a vůbec v celé naší literární tradici je vztah mezi lidem a ,zbojníkem zcela jiný, je v něm sympatie porobeného lidu k jeho mstiteli, jak je přirozené u národa, který byl po staletí národnostně i sociálně utlačován.“

Kromě všech uvedených př́íkladi̊ z Thomasova nového překladu „Máje“ budí rozpaky i překladatelovo rozhodnutí vypustit z Máchovy skladby obě intermezza: ačkoliv rýmovaná (pseudo)vlastenecká dedikace k „Máji“ je něčím, co bývá z českých i cizojazyčných verzí Máchovy básně právem vyškrtnuto, v případě intermezz žádný legitimní důvod k vynechání nevidíme. 
„Máj" patř́í k nejpřekládanějším dílům české poezie. Možná je dokonce naší nejpřekládanější básní vůbec ( $\mathrm{k}$ jednoznačnějšímu konstatování chybí přesnější srovnávací statistika). ${ }^{11}$ Přesto zůstává smutným faktem, že za hranicemi naší země nemají běžní čtenáři o této vrcholné básni českého romantismu ani základní povědomí. Znalost Máchova „Máje“ je v cizině výhradně věcí literárních zasvěcenců.

Obáváme se, že Thomasův překlad na světové nepopularitě „Máje“ nic nezmění. Překlad Ginsburgův, dnes už jen obtížně dostupný, by však stálo za to vydat znovu. Jeho kvality jsou - zvlášt na pozadí nového př̀kladu Thomasova - zcela nesporné.

\section{BIBLIOGRAFIE}

Koloc, Miroslav (2010) 'Karel Hynek Mácha: Máj. Anotovaný soupis vydání (23. 4. 1836 - 16. 11. 2010)', in Týž, Ustavičné senzace poutníka Karla Hynka Máchy, Praha: Triáda, nestránkované CD.

Levý, Jiří (1950) 'K. H. Mácha’s Máj Translated into English', Časopis pro moderní filologii 33(3): 36-38.

(1971) ‘O překládání Máchova Máje’, in Týž, Bude literární věda exaktní vědou?, Praha: Československý spisovatel, 158-167.

Mácha, Karel Hynek (1959) 'Máj', in Týž, Dílo I, Praha: Státní nakladatelství krásné literatury, hudby a umění, 21-53.

'May' (přel. Alfred Thomas), rukopis.

(2000) 'May' (přel. James Naughton): http://babel.mml.ox.ac.uk/naughton/macha2.html (access:

12. 3. 2018).

(1932) 'May' (přel. Roderick A. Ginsburg), soukromé vydání.

Mukařovský, Jan (1948) Kapitoly z české poetiky III. Máchovské studie, Praha: Svoboda.

Rubáš, Stanislav (2012) 'In the Image of Their Muse: The Pinnacle of Czech Poetry with a Western and Eastern Touch', AUC Philologica 2/2011, Translatologica Pragensia VIII: 167-187.

Sulak, Marcela (2005) 'Introduction', in Karel Hynek Mácha, May, Prague: Twisted Spoon Press, 7-16.

\section{PEЗЮME}

В 1950 году основоположник чешской теории перевода Иржи Левый посвятил две статьи иноязычным переводам поэмы «Май» (1836) Карла Гинека Махи (1810-1836), принадлежащей к вершинам чешской поэзии. Исходя из анализа английских переводов поэмы, Левый показал, как изменился «идейно-стилистический фонд подлинника» под влиянием литературных стереотипов и клише принимающей англоязычной культуры. В итоге Маха, наделенный особым философским укладом души и идущий наперекор времени, за пределами чешской литературы является всего лишь эпигоном Байрона, или, точнее сказать, наследником байроновской романтической образности и фатализма. Наш анализ посвящен новому (пока еще неопубликованному) переводу маховской поэмы на английский, выполненному американским славистом Альфредом Томасом. Сравнив оригинал с переводом, мы пришли к выводу, что переводчику не удалось про-

11 Kromě angličtiny byl celý „Máj“ přeložen do bengálštiny (jednou), běloruštiny (jednou), bulharštiny (trrikrát), čínštiny (jednou), esperanta (dvakrát), francouzštiny (třikrát), italštiny (dvakrát), japonštiny (jednou), lužické srbštiny (jednou), madarštiny (dvakrát), němčiny (osmkrát), polštiny (dvakrát), ruštiny (čtyřikrát), slovenštiny (jednou), slovinštiny (třikrát), srbocharvátštiny (jednou), španělštiny (dvakrát), švédštiny (jednou) a ukrajinštiny (třikrát). Uvedené údaje se týkají pouze kompletních publikovaných překladů (kromě nich existuje řada překladů torzovitých a/nebo takových, jež zůstaly pouze $\mathrm{v}$ rukopise). 
никнуть в систему метрических и семантических пластов подлинника и что многие его решения можно охарактеризовать как смысловой сдвиг, «отсебятину» и даже явную ошибку. Кроме того, примеры из первого перевода «Мая» на английский, изданного самиздатом в 1932 г., доказывают, что в новой версии поэмы, в отличие от более раннего перевода Родерика А. Гинзбурга, маховский ритм и оригинальная метафорика не передаются с максимально возможной адекватностью. Итак, новому переводу, по всей вероятности, не удастся привлечь внимание англоязычной читательской публики к наиболее значимой романтической поэме чешской литературы.

PhDr. Stanislav Rubáš, Ph.D.

Ústav translatologie, Filozofická fakulta Univerzity Karlovy, Praha

stanislav.rubas@ff.cuni.cz 